\title{
An Overview Water Resources Management in Turkey
}

\author{
Murat Topal* \\ Department of Environmental Engineering, University of Munzur, Turkey
}

*Corresponding author: Murat Topal, Department of Environmental Engineering,

University of Munzur, Turkey.

Received Date: March 28, 2019

Published Date: April 15, 2019

\section{Editorial}

In Turkey, there are surface and underground water resources. However, environmental pollution due to rapid urbanization and industrialization causes pollution of our fresh water resources. This situation has a negative impact on living beings as well as many environmental problems. For these reasons, it is necessary to protect our water resources and prevent pollution. The most important structures in the management of water resources are dams and ponds. Thanks to the dams, water needs for both drinking and irrigation can be met. Food safety can never be guaranteed when water resources are not suitable to meet the required irrigation requirements. This problem is becoming increasingly serious in most countries, with the rapid increase in population and high dependence on agriculture [1]. To solve the problem of irrigation water scarcity, surface water and groundwater are used for irrigation. However, intensive agricultural activities increase the need for groundwater due to shortage of surface water. This situation leads to many environmental problems such as the reduction of groundwater table and salinity [2,3]. Considering that the largest water user in the world is the agricultural sector [4], it is imperative to rethink the use and management of water in this sector [5]. The assessment of water management is increasingly important to determine the appropriateness of water resources. This situation is becoming important especially in arid environments where the highest competition for these resources exist and is expected to increase in the 21st century [5]. Climate studies to date predict that the availability of water resources in the Mediterranean region will decrease. The decrease in precipitation and an increase in temperatures [6,7] will cause significant results on regional water balance [5]. The water resources management in the Mediterranean Sea, which is located on the coast of Europe, faces various challenges depending on the variable rain situations and high irrigation needs [8-10]. It is thought that the climate will change in the future because of the hotter and drier conditions in this region which reduce the appropriate water resources [10-13].
For these reasons, it is necessary to continuously monitor the water quality of the waters to be used for agricultural purposes.

Although water resources cover a significant part of the world's surface, the amount of clean water reserves in the world is quite low. Especially in developing countries, fresh water reserves are decreasing day by day due to contamination. Therefore, the issue of water pollution is an important issue for many developing countries. Water is a very important resource on the surface of the world and water resources need to be managed well. In order to manage water resources correctly, water quality needs to be assessed [14]. Monitoring of physicochemical and biological parameters in water resources, provides information about the quality and use of water resources. In this context, monitoring of the quantity and quality of water resources, conservation and measures to be taken in order to achieve good water status are indicated by the Surface Water Quality Regulation in Turkey [15]. Specific pollutants and environmental quality standards in surface water sources are given in the regulation. The Water Framework Directive (WFD) sets out the basic principles for guiding sustainable water policies in the European Union. One of the objectives of the Directive is to provide protection and development of aquatic ecosystems with special preventions such as reducing, preventing or disabling the discharge of priority substances. The main objective of the Directive is to prevent the deterioration of the condition of all surface water bodies and to achieve a good situation in all water bodies in member states [16]. The Water Framework Directive (WFD) sets out the basic principles for guiding sustainable water policies in the European Union. The Directive covers all water bodies, including surface water and groundwater, all inland waters, transitional waters and coastal waters up to 1 nautical mile (1852 m). The objectives of the Directive are to protect and improve water resources and to prevent deterioration in quality; ensuring sustainable, balanced and equitable water use for long-term conservation of water resources; protection and improvement of the aquatic ecosystem 
with special measures such as reduction of discharge and emission of priority substances and preventing priority hazardous materials or preventing discharging of priority hazardous materials; by reducing groundwater pollution and preventing further pollution; contributing to mitigation of impacts caused by floods and droughts. The main objective of the Directive is to prevent the deterioration of all surface water bodies and to achieve good status in all water bodies in the Member States as of 2015. Good condition for surface water is achieved by achieving good ecological status and good chemical condition. It was promised to achieve good water condition in all surface water bodies until 2027 by Turkey in negotiation document. Matters related to water quality monitoring are defined in Article 8 and Annex-5 of the Water Framework Directive. The Regulation on the Monitoring of Surface Waters and Groundwater within the scope of the harmonization of the WFD to the legislation of Turkey entered into force after being published in the Official Gazette dated 11.02.2014 and numbered 28910. With this regulation, the provisions of Article 8 and Annex-5 of the WFD have been completely transposed into Turkey' s national legislation [17].

\section{Acknowledgement}

None.

\section{Conflict of Interest}

No conflict of interest.

\section{References}

1. FAO (2015) Food and Agriculture Organization of the United Nations.

2. Liu J, Li YP, Huang GH, Zhuang XW, Fu HY (2017) Assessment of Uncertainty Effects on Crop Planning and Irrigation Water Supply Using a Monte Carlo Simulation Based Dual-Interval Stochastic Programming Method, Journal of Cleaner Production 149: 945-967.

3. Mishra AK, Kumar B, Dutta J (2016) Prediction of Hydraulic Conductivity of Soil Bentonite Mixture Using Hybrid-ANN Approach, Journal of Environmental Informatics 27: 98-105.

4. FAO (2006) Agricultural Outlook 2006-2015. Food and Agriculture Organization of the United Nations.

5. García-Garizábal I, Causapé J, Merchán D (2017) Evaluation of Alternatives for Flood Irrigation and Water Usage in Spain Under Mediterranean Climate, CATENA 55: 127-134.
6. IPCC (2007) In: Core Writing Team, Pachauri RK, Reisinger A (Eds.) Climate Change 2007: Synthesis Report. Contribution of Working Groups I, II and III to the Fourth Assessment Report of the Intergovernmental Panel on Climate Change. IPCC, Geneva. p.220.

7. IPCC (2008) Climate Change and Water. Cambridge University Press, Cambridge, United Kingdom, p.120.

8. EEA (2012) Water resources in Europe in the context of vulnerability. State of Water Assessment. EEA Report no. 11/2012. European Environmental Agency (EEA), Copenhagen, p.100.

9. Iglesias A, Garrote L, Diz A, Schlickenrieder J, Martin-Carrasco F (2011) Re-Thinking Water Policy Priorities in the Mediterranean Region in View of Climate Change, Environmental Science and Policy 14: 744-757.

10. Nunes JP, Jacinto R, Keizer JJ (2017) Combined Impacts of Climate and Socio-Economic Scenarios on Irrigation Water Availability for A Dry Mediterranean Reservoir, Science of The Total Environment, 584-585: 219-233.

11. Collins M, Knutti R, Arblaster J, Dufresne JL, Fichefet T, et al. (2013) Longterm climate change: projections, commitments and irreversibility. In: Stocker TF, Qin D Plattner, G-K Tignor M, Allen SK, Boschung J, et al. (Eds.) Climate Change 2013. The Physical Science Basis. Contribution of Working Group I to the Fifth Assessment Report of the Intergovernmental Panel on Climate Change. Cambridge University Press, Cambridge and New York, p.1136.

12. García-Ruiz JM, López-Moreno II, Vicente-Serrano SM, Lasanta-Martínez T, Beguería S (2011) Mediterranean Water Resources in A Global Change Scenario, Earth Science Reviews 105: 121-139.

13. Kovats RSS, Valentini R, Bouwer LMLM, Georgopoulou E, Jacob D, et al. (2014) Europe. In: Barros VR, Field CB, Dokken DJ, Mastrandrea MD, Mach KJ, et al. (Eds.) Climate Change 2014: Impacts, Adaptation, and Vulnerability. Part B: Regional Aspects. Contribution of Working Group II to the Fifth Assessment Report of the Intergovernmental Panel on Climate Change. Cambridge University Press, Cambridge and New York, USA, p.1326.

14. Uddin Md G, Moniruzzaman Md, Quader MA, Abu Hasan Md (2018) Spatial variability in the distribution of trace metals in groundwater around the Rooppur nuclear power plant in Ishwardi, Bangladesh, Groundwater for Sustainable Development 7: 220- 231.

15.SWQR (2012) Surface Water Quality Regulation 30.11.2012 Tarih ve 28483 sayılı Resmi Gazete.

16. Topal M, Arslan Topal EI (2017) Determination of Concentrations of Lead and Nickel in Keban Dam Lake (Elazığ) within Water Framework Directive, Int J Pure Appl. Sci 3(1): 41-53.

17. FDH (2015) Frrat-Dicle Havzası su kalitesi izleme programı. Orman ve Su İșleri Bakanlığı, Su Yönetimi Genel Müdürlügü, Ankara, 140s. (in Turkish). 